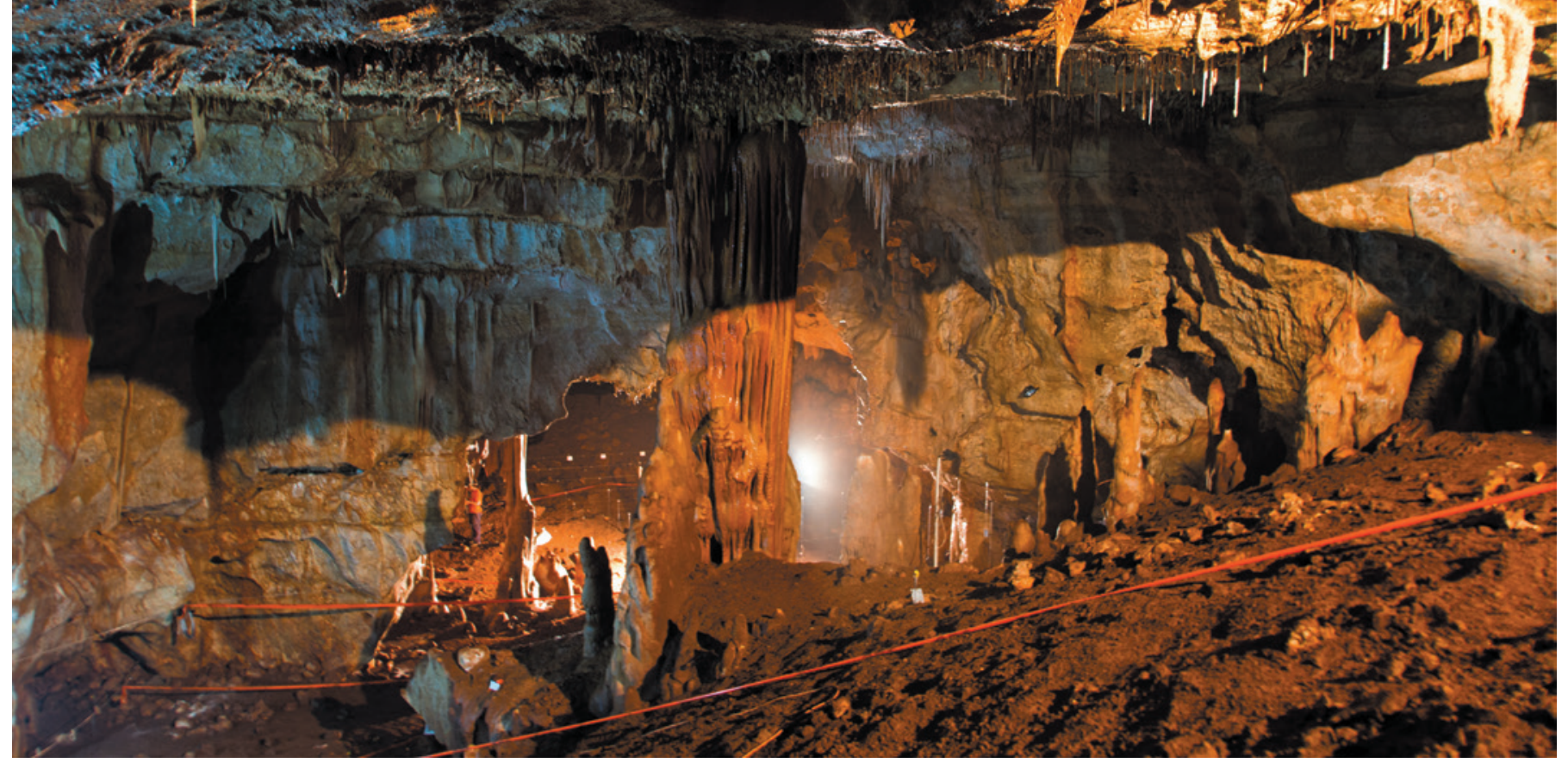

Manot Cave, near Israel's Sea of Galilee, was rediscovered when a bulldozer opened an entrance to it in 2008.

\title{
Neanderthals gain human neighbour
}

\section{Cranium discovery shows that Homo sapiens was living in Middle East 55, 000 years ago.}

\section{BY EWEN CALLAWAY}

A 55,000-year-old incomplete skull found in Israel may belong to a human group that interbred with Neanderthals. Discovered deep in a cave by amateur speleologists, the partial cranium also fills a major gap in the fossil record of Homo sapiens' journey from Africa to Europe.

"Here we actually hold a skull of a human being that was living next to the Neanderthals," says Israel Hershkovitz, the leader of a study published today in Nature (I. Hershkovitz et al. Nature http://dx.doi.org/10.1038/nature14134; 2015). "Potentially he is the one that could interbreed with the Neanderthals," says Hershkovitz, who is a physical anthropologist at Tel Aviv University in Israel.

Genome studies of Neanderthals (Homo neanderthalensis) and of both ancient and contemporary $H$. sapiens suggest that the two species interbred somewhere in the Middle East between 50,000 and 60,000 years ago (Q. Fu et al. Nature 514, 445-449; 2014). But the problem with this idea is that no remains of anatomically modern humans have been discovered in the Middle East from this crucial period, after $H$. sapiens left Africa and before it colonized Europe and Asia.

In 2008, a bulldozer clearing land for a development near the Sea of Galilee in northern Israel revealed an opening to a limestone cave that had been sealed for more than 15,000 years. Amateur speleologists were the first to explore the cave, and they spotted the battered bone - the top portion of a skull - resting on a ledge. The Israel Antiquities Authority soon

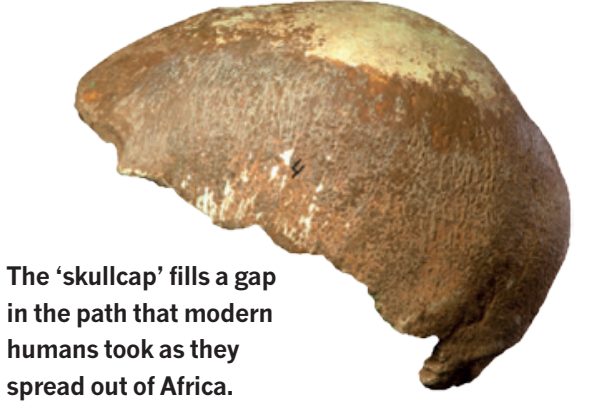

launched a complete survey of Manot Cave, finding buried stone tools at several spots that are still being excavated.

The skull was unquestionably from $H$. sapiens, says Hershkovitz: it was similar in shape to those of earlier African and later European humans. A patina of calcite coated the fragment, and the researchers used radioactive uranium in the mineral to date the bone to about 55,000 years old. That means that "the Manot people are probably the forefathers of the early Palaeolithic populations of Europe", Hershkovitz says.

The Manot people are also a leading candidate for the humans that bred with Neanderthals - exploits that have given all of today's non-African humans a sliver of Neanderthal heritage. The Manot Cave is not far from two other sites that held Neanderthal remains of a similar age. "The southern Levant is the only place where anatomically modern humans and Neanderthals were living side by side for thousands and thousands of years," Hershkovitz says. The ultimate proof would be to look for the presence of Neanderthal ancestry in DNA from the skull, but the region's balmy temperatures mean that ancient DNA is unlikely to have been preserved.

Jean-Jacques Hublin, a palaeoanthropologist at the Max Planck Institute for Evolutionary Anthropology in Leipzig, Germany, agrees that the chances of recovering DNA from the skull fragment are slim. But he hopes that further excavations will find human remains that have stayed cool enough to still contain DNA. These digs might also connect the skull to stone tools and other relics of daily life, which could strengthen the Manot skull's link to early Europeans. The artefacts uncovered so far are thought to be much younger than the skull. "We have a skull, and we have a site where there is some archaeology, but there is no link between the skull and the archaeology. It's a bit annoying," Hublin says.

"This specimen is really important and exciting, as - assuming the dating is correct - it shows for the first time that modern humans existed in the Near East at the same time as Neanderthals," says Katerina Harvati, a palaeoanthropologist at the University of Tübingen in Germany. "Until now we had no evidence that the two even coexisted in this region during this time period. So this is a crucial piece of the puzzle." — SEE EDITORIAL P.527

\section{CORRECTION}

The News Feature 'Laser focus' (Nature 517, 430-432; 2015) gave the wrong amount for the funding behind the Center for Adaptive Optics. The grant was in fact for around US $\$ 40$ million over 10 years. 